\title{
Comparative analysis of hysteroscopy versus suction evacuation in the management of retained product of conception
}

\author{
Harish K. M. ${ }^{1 *}$, Shwetha N. ${ }^{1}$, Dipankar Debnath ${ }^{2}$
}

\author{
${ }^{1}$ Department of Obstetrics and Gynecology, Malabar Medical College, Calicut, Kerala, India \\ ${ }^{2}$ Department of Obstetrics and Gynecology, Regional Institute of Medical Sciences, Imphal, Manipur, India
}

Received: 24 April 2018

Accepted: 30 April 2018 Malabar Medical College, Calicut, Kerala

\author{
*Correspondence: \\ Dr. Harish K. M., \\ E-mail: kmharish07@gmail.com
}

Copyright: (c) the author(s), publisher and licensee Medip Academy. This is an open-access article distributed under the terms of the Creative Commons Attribution Non-Commercial License, which permits unrestricted non-commercial use, distribution, and reproduction in any medium, provided the original work is properly cited.

\begin{abstract}
Background: RPOC can occur due to spontaneous or induced abortion followed by incomplete or partial expulsion of product of conception. Suction evacuation is currently the standard surgical treatment, but operative hysteroscopy has the advantage over Suction evacuation allowing the direct visualization of the retained conception product, facilitating its elective removal while limiting surgical complications.

Methods: Comparative retrospective study of 80 patients who presented with RPOC during the period of 6 months. Hysteroscopy was done in 40 patients and Suction evacuation in remaining 40 patients. Data regarding anaesthesia required, mean time taken for procedure and post procedure hospital stay, complication due to the procedure and postoperative outcome were collected to compared,

Results: In hysteroscopy group none of patients required anaesthesia and even though mean time taken for the procedure is 2 minutes more in hysteroscopy group without statistical significant difference (P 0.672), the post procedure hospital stay is less compared to suction evacuation group. Complication due to procedure was seen in 5 $(12.5 \%)$ patients in hysteroscopy group which is less compared to $13(32.5 \%)$ patients in suction evacuation group. Mean number of days of pain requiring analgesia and Sick leave applied was also less in hysteroscopy group (1 day and 2 days respectively) group compared to suction evacuation group ( 9 days and 7 days respectively)

Conclusions: Lesser rates of intra and post-operative complications with hysteroscopy makes the procedure 'safe' to the patients and 'effective' as it ensures complete evacuation of the uterine cavity under direct vision and reduce the need for repeat procedure.
\end{abstract}

Keywords: Hysteroscopy, Incomplete miscarriage, Pregnancy loss, Suction evacuation, Vacuum aspiration

\section{INTRODUCTION}

The term retained products of conception (RPOC) refers to intrauterine tissue that develops after conception and persists after medical and surgical pregnancy termination, miscarriage, and vaginal or caesarean delivery. This intrauterine tissue is often of placental origin. ${ }^{1}$

It complicates $1-5 \%$ of all pregnancies. RPOC was present in after a third-trimester delivery in around $2.7 \%$ of women, whereas it was diagnosed in pregnancies ending during the second and first trimesters in $40 \%$ and $17 \%$, respectively. ${ }^{2}$

Various medical and surgical methods have been employed in the treatment of retained products of conception (RPOC). Amongst the surgical methods the universally accepted technique is simple dilatation and curettage. $^{3}$ Other surgical procedures are suction evacuation and operative hysteroscopy, which is 
increasingly used for treatment of retained products of conception (RPOC) following different types of abortions. $^{4}$

Suction evacuation is currently the standard surgical treatment in most centres. However, it is typically carried out in a blind manner, and can therefore lead to the persistence of intrauterine retention, which may not be diagnosed initially. ${ }^{5}$ Even after medical evacuation, 30$50 \%$ of women undergo a surgical procedure because of the suspicion of incomplete evacuation. ${ }^{6}$

Hysteroscopy is another beneficial surgical treatment which makes it possible to visualize the retention product, its elective removal and the integrity of the cavity directly, without trauma to the adjacent endometrium, while limiting the complications of surgery and the number of repeat interventions due to retention. ${ }^{7}$

Not many studies were found comparing the hysteroscopy and suction evacuation in this part of the country. The studies regarding safety and effectiveness of hysteroscopy are lacking.

\section{METHODS}

Present study was a comparative retrospective study to analyze between Hysteroscopy and suction Evacuation in management of first trimester abortions (induced and spontaneous). The study period was from August 2016 to December 2016

\section{Inclusion criteria}

- Patients presenting with trophoblastic intrauterine retention following incomplete spontaneous or induced abortion in first trimester $(<12$ weeks of amenorrhea)

- The pregnancy was confirmed with urine pregnancy test and PROC was diagnosed by combination of both clinical and trans-vaginal pelvic ultrasound showing a heterogeneous intrauterine mass and an intrauterine sac over $15 \mathrm{~mm}$ thick.

- Selected patients were managed surgically, when expectant and medical management is not acceptable or has failed or in case of sepsis, heavy bleeding or hemodynamic instability and written consent was taken.

\section{Exclusion criteria}

- Known uterine malformations

- History of surgical treatment for intrauterine retention

- Intrauterine retention of material over $50 \mathrm{~mm}$ thick, diagnosed by transvaginal pelvic ultrasound

- Emergency haemostatic therapy to treat heavy vaginal bleeding (haemorrhagic miscarriage)

- Presence of an intrauterine device
- $\quad$ Ongoing pregnancy or extra uterine pregnancy.

80 patients were found to have RPOC. Among them 40 patients with RPOC had underwent Hysteroscopy and remaining 40 patients had underwent suction evacuation.

- Number of cases: 80

- Number of cases managed by Hysteroscopy: 40

- Number of cases managed with Suction evacuation: 40

Patients had received preoperative single $200 \mathrm{mg}$ dose of doxycycline, 1 hour before surgical management of early pregnancy loss to prevent postoperative infection. Misoprostol or other prostaglandins was not used for cervical ripening. Suction evacuation performed was according to department protocol for all patients who underwent this procedure. The cervix if not dilated, Hegar dilator number 9 was used to dilate the cervix with the patient under general anesthesia, and section evacuation was performed with a karman's canula of appropriate size fitted to suction apparatus.

Hysteroscopic transcervical resection under office settings without anaesthesia was carried out with a standard $26 \mathrm{~F}$ continuous-flow resectoscope fitted with a 4-mm cutting loop. The uterine cavity was distended with saline solution administered with a flow-controlled Hysteroflator (Karl Storz). RPOC was removed mechanically using the loop and gentle motions without application of current.

All patients were reviewed at one week and two weeks after procedure. Product of conception was confirmed by histopathology in all cases.

Following parameters and outcome documented was retrieved from the register:

- Characteristic of the patients such as age, parity, period of gestation, h/o previous caesarean section, $\mathrm{h} / \mathrm{o}$ previous abortion and mode of conception

- Variables such as anaesthesia required during procedure, mean time taken for procedure and number of days in hospital

- Immediate complications such as very heavy vaginal bleeding (i.e. soaking through sanitary towels every 15 minutes or passing clots the size of the palm of hand), fever due to infection and incomplete procedure resulting in retained fetal tissue. Serious complications such as cervical trauma, perforation of uterus.

- Post-operative outcomes measured were the number of days of pain requiring analgesia and the number of day's sick leave applied.

The data was analysed using the Statistical Package for the Social Sciences (SPSS, version 16 for Windows, Chicago, IL, USA). Groups were compared using an 
unpaired Student's $t$-test for normally distributed variables, and fischer exact test (FET) for individual postoperative complications. $\mathrm{P}$ value of $<0.05$ was taken as significant.

\section{RESULTS}

Characteristic of patients in present study shows majority of patients were Primiparous $(40 \%)$, within the age group of 20 to $29 \mathrm{yrs}(67.5 \%)$, with period of gestation less than 6 weeks $(67.5 \%)$. Patients with history of previous caesarean section $(22.5 \%)$ and abortion $(5 \%)$ were less. Only 2 patients $(2.5 \%)$ had conceived by assisted reproductive technique.

Table 1: Characteristic of patients.

\begin{tabular}{|c|c|c|c|}
\hline \multicolumn{2}{|c|}{ Characteristic of patients } & No. & $\%$ \\
\hline \multirow{4}{*}{ Age } & $<19$ years & 6 & 7.5 \\
\hline & $20-29$ years & 54 & 67.5 \\
\hline & 30 years and above & 20 & 25 \\
\hline & Total & 80 & 100 \\
\hline \multirow{4}{*}{ Parity } & $\mathrm{P} 0+0$ & 32 & 40 \\
\hline & $\mathrm{P} 1+0$ & 26 & 32.5 \\
\hline & P2 and above & 22 & 27.5 \\
\hline & Total & 80 & 100 \\
\hline \multirow{3}{*}{$\begin{array}{l}\text { Period of } \\
\text { gestation }\end{array}$} & $<6$ weeks & 54 & 67.5 \\
\hline & 6-12 weeks & 26 & 32.5 \\
\hline & Total & 80 & 100 \\
\hline \multirow{3}{*}{$\begin{array}{l}\text { h/o Previous } \\
\text { CS }\end{array}$} & Yes & 18 & 22.5 \\
\hline & No & 62 & 77.5 \\
\hline & Total & 80 & 100 \\
\hline \multirow{3}{*}{$\begin{array}{l}\text { h/o Previous } \\
\text { abortion }\end{array}$} & Yes & 04 & 05 \\
\hline & No & 76 & 95 \\
\hline & Total & 80 & 100 \\
\hline \multirow{3}{*}{$\begin{array}{l}\text { Mode of } \\
\text { conception }\end{array}$} & Spontaneous & 78 & 97.5 \\
\hline & Assisted & 02 & 2.5 \\
\hline & Total & 80 & 100 \\
\hline
\end{tabular}

Table 2 shows that none of the patients required anaesthesia in hysteroscopy group whereas all the patients in suction evacuation group procedure done was under general anaesthesia.

The difference in anaesthesia requirement in two groups is statistically significant with $\mathrm{p}$ value 0.0001 . Even though mean operative time taken for Hysteroscopy (17min) was more compared to Suction evacuation (15min), the difference is statistically not significant with $\mathrm{p}$ value 0.067 . Number of days of hospital stay required after the procedure was more in S/E group with statistical significant difference ( $\mathrm{p}$ 0.0001).

In S/E group $27(67.5 \%)$ patients needed admission and observation for 24 hours and $13(32.5 \%)$ patients needed more than 1 day whereas in Hysteroscopy group 35 $(87.5 \%)$ patients were managed on day care basis, only 4 $(2.5 \%)$ patients were admitted for 24 hours and 1 patient admitted for more than 1 day.
Table 2: Operative outcome.

\begin{tabular}{|llll|}
\hline & $\begin{array}{l}\text { Hysteroscopy } \\
\mathrm{n}=40\end{array}$ & $\begin{array}{l}\text { Suction } \\
\text { evacuation } \\
\mathrm{n}=40\end{array}$ & $\begin{array}{l}\mathrm{P} \\
\text { value }\end{array}$ \\
\hline $\begin{array}{l}\text { Anaesthesia } \\
\text { required }\end{array}$ & 0 & $40(100 \%)$ & 0.0001 \\
\hline $\begin{array}{l}\text { Mean time } \\
\text { taken for } \\
\text { Procedure }\end{array}$ & $17 \mathrm{~min}$ & $15 \mathrm{~min}$ & 0.672 \\
\hline $\begin{array}{l}\text { Post procedure } \\
\text { hospital stay }\end{array}$ & $35(87.5 \%)$ & $0(0 \%)$ & 0.0001 \\
\hline $\begin{array}{l}\text { Day Care } \\
\text { 24 Hours }\end{array}$ & $4(10 \%)$ & $27(67.5 \%)$ & \\
\hline$>1$ Day & $1(2.5 \%)$ & $13(32.5 \%)$ & \\
\hline
\end{tabular}

Table 3 shows, after suction evacuation 13 (32.5\%) patients were identified to have complication and 27 were asymptomatic. Among 9(22.5\%) patients admitted with heavy vaginal bleeding, 2 patients reported persistent vaginal bleeding required blood transfusion, 2 patients were found to have retained fetal tissue diagnosed by repeat ultrasound, 1 patient had uterine perforation requiring laparoscopic intervention and 1 had cervical trauma, while the remaining 3 cases were treated conservatively. Those 4 patients who presented with fever were hospitalized for treatment with intravenous antibiotics.

Table 3: Complications.

\begin{tabular}{|llll|}
\hline & $\begin{array}{l}\text { Hysteroscopy } \\
\mathrm{n}=40\end{array}$ & $\begin{array}{l}\text { Suction } \\
\text { evacuation } \\
\mathrm{n}=40\end{array}$ & $\begin{array}{l}\mathrm{P} \\
\text { value }\end{array}$ \\
\hline $\begin{array}{l}\text { Complications } \\
\text { seen in }\end{array}$ & $5(12.5 \%)$ & $13(32.5 \%)$ & 0.030 \\
\hline $\begin{array}{l}\text { Frequent complication } \\
\text { Bleeding }\end{array}$ & $9(22.5 \%)$ & 0.112 \\
\hline $\begin{array}{l}\text { Heavy } \\
\text { bleeding }\end{array}$ & $4(10 \%)$ & $2(5 \%)$ & 0.247 \\
\hline $\begin{array}{l}\text { Requiring } \\
\text { blood } \\
\text { transfusion }\end{array}$ & $0(0 \%)$ & $4(10 \%)$ & 0.179 \\
\hline $\begin{array}{l}\text { Infection } \\
\begin{array}{l}\text { Retained fetal } \\
\text { tissue }\end{array}\end{array}$ & $1(2.5 \%)$ & $2(5 \%)$ & 0.058 \\
\hline $\begin{array}{l}\text { Serious side effects } \\
\text { Perforation of } \\
\text { uterus }\end{array}$ & $0(0 \%)$ & $1(2.5 \%)$ & 0.5 \\
\hline \begin{tabular}{l} 
Cervical trauma \\
\hline
\end{tabular} & $0(0 \%)$ & $1(2.5 \%)$ & 0.5 \\
\hline
\end{tabular}

Complications were less in hysteroscopy group compared to Suction evacuation group which is statistically significant with $\mathrm{p}$ value 0.030 . In hysteroscopy out of 5 patients, who had frequent complication only $4(12.5 \%)$ patients had heavy vaginal bleeding which was treated conservatively and 1 patient with fever was admitted for intravenous antibiotics. None of patients required blood transfusion or had serious side effects such as uterine 
perforation and cervical trauma. Complete removal of pregnancy tissue was achieved in all the cases. No case required a further repeat procedure for retained fetal tissue. All the individual complications had no statistical significant difference with $\mathrm{p}>0.05$.

Table 4: Post-operative outcome.

\begin{tabular}{|llll|}
\hline & $\begin{array}{l}\text { Hysteroscopy } \\
\mathrm{n}=40\end{array}$ & $\begin{array}{l}\text { Suction } \\
\text { evacuation } \\
\mathrm{n}=40\end{array}$ & $\begin{array}{l}\mathrm{P} \\
\text { value }\end{array}$ \\
\hline $\begin{array}{l}\text { Mean number } \\
\text { of days of } \\
\text { pain requiring } \\
\text { analgesia }\end{array}$ & 1 day & 5 days & 0.0001 \\
\hline $\begin{array}{l}\text { Sick leave } \\
\text { (mean days) }\end{array}$ & 2 days & 7 days & 0.0001 \\
\hline
\end{tabular}

Table 4 shows mean number of days of "pain requiring analgesia and sick leave applied" was more in Suction evacuation group (5 days and 7 days respectively) compared to Hysteroscopy group (1 days and 2 days respectively) which is statistically significant ( $\mathrm{p}$ value $<0.0001)$.

\section{DISCUSSION}

Retained products of conception (RPOC) may cause prolonged bleeding and endometritis if left untreated. On the other hand, blind procedure of suction and curettage for evacuation of the uterine cavity after first-trimester miscarriage is associated with the risk of complications such as perforation, hemorrhage and infection. So, the correct selection of type of surgical procedure is a desirable goal. ${ }^{8}$ Present study shows primiparous women, age within 20 to 29 years, below 6 weeks of gestation are at high risk of retained product of conception. Patients with history of previous abortion (5\%) and caesarean section $(22.5 \%)$ were less. Only 2 patients had conceived by assisted reproductive technique.

Suction evacuation of RPOC is done under anaesthesia and requires hospitalization. Even though suction evacuation offers the greatest complete evacuation rate, the least risk of need for unplanned admission, and the shortest duration of bleeding, the results are not comparable to hysteroscopy management. Present study shows that rate of complication such as bleeding (22\%), infection $(10 \%)$, the risk of perforation $(2.5 \%)$, cervical trauma $(2.5 \%)$ and need for repeat evacuation due to persistent residual tissue was higher in suction evacuation group $(5 \%)$. Whereas still higher rate of persistent residual tissue in patients who underwent Suction evacuation was seen in study of Shlomo B et al. ${ }^{9}$ Five $(20.8 \%)$ patients who underwent traditional curettage later required operative hysteroscopy due to persistent residual tissue

Hysteroscopy for RPOC has advantage as the procedure is done without anaesthesia, thereby preventing anaesthesia related complication. Even though procedure time is 2 min more compared to suction evacuation, the difference is statistically not significant (p 0.672). It also reduces the duration of hospital stay; thereby early regain of activity and less number of days of sick leave (mean 2days). Duration of pain suffered is less (mean 1 day), thereby reducing the intake of analgesics. In 35(87.5\%) patients post-operative period was uneventful whereas complication was seen in $5(12.5 \%)$ patients. The results were comparable to that of Hamerlynck et al. ${ }^{10}$ Complications such as bleeding (10\%), infection (2.5\%), was less where there was no risk of perforation, cervical trauma and need for repeat evacuation.

The present study describes lesser rates of complications with hysteroscopy thereby making the procedure 'safe' to the patients and 'effective' as it ensures complete evacuation of the uterine cavity under direct vision and reduces the need for repeat procedure. Hysteroscopy may also facilitate the diagnosis of abnormalities or diseases of the uterine cavity (fibroids, polyps), which may be responsible for spontaneous abortions. These abnormalities may be amenable to surgical treatment, improving the management of patients and their prognosis.

Because of small number of cases and its retrospective design the current study has its limitations. In addition, operative hysteroscopy because of its high cost and need for surgeon's experience, may not be available to all patients requiring uterine evacuation for incomplete medical abortion. Thus, our findings may not be applicable to many women undergoing medical abortion in low resources areas.

\section{CONCLUSION}

In conclusion, hysteroscopy allows for removal of RPOC following medical abortion. This procedure is safe and effective with low rates post-operative complications. It should therefore continue to be offered as a management option, particularly to those women with RPOC.

\section{ACKNOWLEDGMENTS}

The authors are thankful to all the faculty and staff members of the Galaxy Care Laparoscopic Hospital, Pune, India for their immense cooperation and support during the study period.

Funding: No funding sources Conflict of interest: None declared

Ethical approval: The study was approved by the Institutional Ethics Committee

\section{REFERENCES}

1. Sellmyer MA, Desser TS, Maturen KE, Jeffrey RB Jr, Kamaya A. Physiologic, histologic, and imaging 
features of retained products of conception. Radiograph. 2013;33:781-96.

2. Van den Bosch T, Daemen A, Van Schoubroeck D, Pochet N, De Moor B. Occurrence and outcome of residual trophoblastic tissue: a prospective study. $\mathrm{J}$ Ultrasound Med. 2008;27(3):357-61.

3. Aseeja V. Management of retained products of conception with marked vascularity. J TurkishGerman Gynecol Assoc. 2012;13:212-4.

4. Smorgick N, Barel O, Fuchs N, Ben-Ami I, Pansky M, Vaknin Z. Hysteroscopic management of retained products of conception: meta-analysis and literature review. Eur J Obstet Gynecol Reprod Biol. 2014;173:19e22

5. Friedler S, Margalioth EJ, Kafka I, Yaffe H. Incidence of post-abortion intra-uterine adhesions evaluated by hysteroscopy: a prospective study. Hum Reprod. 1993;8(3):442-4.

6. Davis AR, Hendlish SK, Westhoff C, Frederick MM, Zhang J, Gilles JM, et al. Bleeding patterns after misoprostol vs surgical treatment of early pregnancy failure: results from a randomized trial. Am J Obstet Gynecol. 2007;196(1):31-e1.

7. Golan A, Dishi M, Shalev A, Keidar R, Ginath S, Sagiv R. Operative hysteroscopy to remove retained products of conception: novel treatment of an old problem. J Minim Invasive Gynecol. 2011;18(1):100-3

8. Abbasi S, Jamal A, Eslamian L, Marsousi V. Role of clinical and ultrasound findings in the diagnosis of retained products of conception. Ultrasound Obstet Gynecol. 2008;32:704-7.

9. Cohen SB, Kalter-Ferber A, Weisz BS, Zalel Y, Seidman DS, Mashiach, S, et al. Hysteroscopy may be the method of choice for management of residual trophoblastic tissue. J Am Assoc Gynecol Laparosc. 2001;8:199-202.

10. Hamerlynck TW, Blikkendaal MD, Schoot BC, Hanstede MM, Jansen FW. An alternative approach for removal of placental remnants: hysteroscopic morcellation. J Minim Invasive Gynecol. 2013;20(6):796-802.

Cite this article as: Harish KM, Shwetha N, Debnath D. Comparative analysis of hysteroscopy versus suction evacuation in the management of retained product of conception. Int J Reprod Contracept Obstet Gynecol 2018;7:2155-9. 